\title{
THE DETERMINANTS OF CORPORATE COMMUNITY CONTRIBUTIONS: SOME INSIGHTS FROM INDONESIAN FIRMS
}

\author{
Tarmizi Achmad \\ Department of Accounting - Diponegoro University, Semarang \\ e-mail: t_achmad@yahoo.com.au \\ Faisal $^{1}$ \\ Department of Accounting - Diponegoro University, Semarang \\ e-mail: faisal@undip.ac.id
}

\begin{abstract}
Using multi lens theoretical framework, this paper investigates the determinants of corporate community contributions in the Indonesian companies setting. Based on a sample of 41 public companies and using data pooled from 2008 through 2011(143 observations), the study finds that corporate community contributions are positively associated with variables relating to ownership and industry type. Further, the results indicate that high profile industries and state-owned enterprises (SOEs) have higher propensity to involve in community contributions. This paper contributes to provide a better understanding related to factors influencing community contributions. This paper is the first of its kind to investigate community contributions in Indonesia.
\end{abstract}

Keywords: community contributions, ownership, industry, stakeholder, legitimacy, Indonesia

\begin{abstract}
Abstrak
Penelitian ini menginvestigasi faktor-faktor yang mempengaruhi praktik filantropi (philantrophy/community contributions/giving) di Indonesia, dengan menggunakan dua perspektif teori, stakeholder dan legitimasi teori. 41 perusahaan publik yang pada periode tahun 2008-2011 digunakan sebagai sampel. Hasil penelitian ini menunjukkan bahwa tipe kepemilikan dan industri mempunyai pengaruh yang signifikan terhadap jumlah rupiah filantropi yang diberikan perusahaan. Lebih jauh, hasil ini menyatakan bahwa Badan Usaha Milik Negara (BUMN) dan perusahaan-perusahaan dalam sektor industri high-profile lebih banyak terlibat dalam aktivitas filantropi (community contributions). Hasil penelitian ini memberikan kontribusi yang signifikan terhadap literatur terkait determinan-determinan aktivitas filantropi (community contributions).
\end{abstract}

Kata kunci: community contributions, kepemilikan, industri, stakeholder, legitimasi, Indonesia

\section{INTRODUCTION}

Corporate responsibility is about company's responsible and sustainable behavior in all company matters, in financial, environmental, and social areas. Community involvement is one section of social areas. Most corporations throughout the world engage in community involvement by doing community contribu-

\footnotetext{
${ }^{1}$ Corresponding Author
}

tions $^{2}$, such as philanthropy, giving, grantmaking, and charitable. This includes gifts to social and charitable causes such as support

\footnotetext{
${ }^{2}$ The term of corporate community contributions are used throughout of the paper. The term of corporate commnity contributions have been used intercha ngeably with corporate charitable involvement (Campbell et al., 2002), corporate charitable contributions (Chen et al., 2008), philanthropy (Amato \& Amato, 2007, 2012), corporate charitable giving (Brammer et al., 2009).
} 
for education, the arts, health care, culture, environmental causes, disaster relief, social services, minorities, and relief funds (Wang and Qian 2011; Smith 2012). For example, some companies provide cash gifts or in-kind gifts for cancer sufferers, equipment, and other products and services. Other companies also donate their employment's time, advice and services instead of cash.

The motivations of companies engage in community contributions may be viewed from two perspectives. First, corporate contributions are seen as a vehicle by which corporations demonstrate concern for society. Collins (1994) argue that corporate community contributions are viewed as creating a win win situation as benefit accrue to the firms as well as those of the beneficiaries (e.g. local community, charitable organizations). Corporate community contributions are also seen as a tool of firms to demonstrate their responsiveness to wide a range of stakeholders in society (Brammer et al. 2009), and therefore, it is recognized as a key component of corporate social responsibility (Porter and Kramer 2002). Second, it represented a capitalistic driver for creating stakeholder support and improved organizational performance, image, goodwill and reputation (Buchholtz et al. 1999; Brammer and Millington 2005).

Prior research suggests that many factors influence community contributions (see Brammer and Millington 2003, 2006; Campbell and Slack 2006; Amato and Amato 2007; Ahmad et al. 2009; Wang and Qian 2011; Kabongo et al. 2012). For instance, Brammer and Millington (2004) argue that community contributions are influenced by stakeholder pressures, firm size, and type of industry. Bartkus et al. (2002) note that community contributions may be subject to managerial selfinterest and managerial discretion level (Buchholtz et al. 1999). Their findings show that block holders and institutional owners limit corporate community contributions. Current study, Cowan et al. (2013) also find that profitability, sales, leverage, and research and development expense are predictors of foreign community contributions.
To date, and to the best of our knowledge, there is scant empirical evidence that examining the determinants of community contributions in Indonesia. This study is focused on the Indonesian firms setting for two reasons. First, most the community contributions studies are based on Anglo-American countries (US, UK and Australia). Evidence should be added about other institutional contexts (Reverte 2009). Second, although there are several studies that investigate the community involvement, these studies only focus on the communication of community involvement as a part of corporate social responsibility (see for example, Mirfazli 2008; Gunawan et al. 2009; Gunawan 2010; Siregar and Bachtiar 2010; Hidayati 2011).

The aim of this study is to investigate what are the factors that explain community contributions made by Indonesian firms. This study contributes to the developing research on corporate community contributions in a number ways. First, research in the area of community contributions is still very sparse, specifically in Indonesia. In the international arena, this area is still under-researched (Ahmad et al. 2009). This study offers valuable insights into factors influencing community contributions. Furthermore, community contributions are important area to be investigated being a growing discretionary item for firms (Buchholtz et al. 1999; Bartkus et al. 2002). Second, the majority of the previous studies investigating community contributions using a theoretical framework such as agency theory (see for example Atkinson and Galaskiewicz, 1988; Buchholtz et al. 1999; Bartkus et al. 2002), stakeholder theory (see for example Adams and Hardwick 1998; Brammer and Millington 2004; Gan 2006; Wang and Qian 2011), legitimacy theory (see for example Dowling and Pfeffer 1975; Campbell et al. 2006), slack resource theory (see for example Amato and Amato 2007; Ahmad et al. 2009). This study adopts two theoretical frameworks, namely stakeholder theory and legitimacy theory as they have some similarities, the agency theory essentially differ on the basis of fundamental assumptions (see theo- 
retical framework section). Gray et al. (1995) argue that if the aim of the study is to explain an empirical phenomenon, it could be a problem when theories are looked upon as competitive instead of complementary. Hence, this study uses a multi theoretical framework in order to explain the determinants of community contributions of Indonesian listed firms.

The research question is to the fore "What are the factors that explain community contributions of Indonesian companies?

\section{THEORETICAL FRAMEWORKS AND HYPOTHESES DEVELOPMENT}

Corporate community contributions have become an increasingly common practice among business (Godfrey and Hatch 2007). It is frequently considered as a construct of business related business and society investigations into corporate social responsibility. Buchholtz et al. (1999) argue that corporate community contribution is a component of the larger domain of corporate social responsibility. Some previous studies define community contributions or philanthropy as follows:

"voluntary activity by citizens and legal persons involving disinterested (gratuitous or at a discount) transfer to individuals or to legal persons of property, including of monetary resources, disinterested fulfillment of work, provision of services, rendering of another support' (Blagov and PetrovaSavchenko 2012, p. 535).

"Corporate philanthropy refers to the voluntary giving of money or other resources including 'in-kind' support (contributions of equipment, supplies or other property) or employee voluntarism by companies for community purposes. By supporting education and training, health and safety, arts and culture, sports and recreation, community services and welfare, and the environment, corporations are providing resources to strengthening non-profit organizations as well as building better society" (Ahmad et al. 2009, p.5).
According to Blagov and PetrovaSavchenko (2012), the reasons for involvement in community contributions activities can be categorized into these groups: appeals by citizens and nonprofit organizations; clients' initiatives; initiatives of employees, owners, and managers; corporate initiative related to sustainable development; and dissemination of practices from an international mother company. These reasons can be subclassified as well. First, the initiative for philanthropic activities can proceed from external and internal stakeholders relative to the organization. Second, corporate philanthropy can be reactive (response to a specific request) or proactive (anticipating initiatives). Third, as one element of corporate social activity, philanthropy develops on the basis of moral choices based on acknowledging the need for socially required corporate behavior, and on an instrumental basis of the need to strengthen competitiveness. Campbell et al. (2002) suggest that there are four possible motivations for corporate community contributions, namely strategic, altruistic, politic, and marginal utility.

The different study stream examining corporate community contributions adopt various theories to explain the phenomena and determinants of community contributions. As argued by Reverte (2009) that despite widespread academic and business interest in the issue, a comprehensive theoretical framework of the underlying determinants of corporate social reporting is still elusive. This study employs multi lens theoretical framework, namely stakeholder theory and legitimacy theory. The two theories will be briefly explained below.

\section{Stakeholder theory}

The stakeholder theory holds that effective management requires the balanced consideration of and attention to the legitimate interests of all stakeholders (Freeman 1984). Corporate success depends on an on going process of stakeholder management in which the interests and demands of stakeholders are identified and dealt with appropriately (Freeman, 1984). Stakeholder perspective emphasizes the relationship managerial decision making and the 
nature of pressures in the company's internal and external environment (Brammer and Millington 2004). Further, they argue that corporate charitable contributions may play a significant role in the process of stakeholder management by enabling managers to demonstrate their commitment to a social agenda, reducing the risk of adverse reactions by internal and external stakeholders. Similarly, Porter and Kramer (2002) suggest that firm may take an instrumental or strategic approach to its stakeholders to manage their impacts on its overall objectives. Corporate community contributions can be regarded as a means by which firms can build better relations with their primary stakeholders (Saiia et al. 2003). Moreover, companies that make substantial contributions are likely to promote a socially responsible public image, this should, in turn, help a firm gain customer support (Adams and Hardwick 1998).

\section{Legitimacy theory}

Chen et al. (2008) argue that legitimacy theory may be used as an alternative theory in explaining community contributions. Past studies show that legitimacy theory has been applied in a number of community contributions studies. For instance, Ashford and Gibbs (1990) and Dowling and Pfeffer (1975) argue that corporate community contributions may be used as a tool of legitimization. That is, firms may make community contributions to project an image of positive image of positive social performance in an effort to mitigate poor social performance in other areas (Chen et al. 2008). From legitimacy theory perspective, firms are involved in corporate community contributions to demonstrate a sense of moral obligation and maintain social legitimacy (Ahmad et al. 2009). From the perspective of legitimacy, Sanchez (2000) argue that one important reason why many firms practice corporate community contributions are to build an image of good corporate citizenship with external constituencies. Moreover, firms use such as philanthropy to help them build strategic relationships and coalitions with the government, the press, other firms, customers, and the public at large.
Bartkus et al. (2002) argue that extravagant community contributions are limited by the powerful owners (i.e. institutions or block holders) since they are more willing to use their power to actively oversee management. Their study finds a negative relationship between community contributions and concentrated ownership. Brammer and Millington (2004) note that the ability of shareholders to influence decisions on corporate community contributions depends on their ability to influence corporate decision makers. As argued by Adams and Hardwick (1998) that manager in firms with concentrated ownership are subject to more intense monitoring from the shareholders, thus, management is less likely to make discretionary community contributions without the consent of the shareholders.

Van der Laan Smith et al. (2005) suggest that differences in ownership structures may affect stakeholder-company relationships and influence the level and quality of corporate social responsibility including the level of community contributions. Li et al. (2013) explain why SoEs engage more in social responsibility compare to Non-SoEs. Further, they argue that the state as owner often has goals that are different from those of private shareholders. For example, it may give more weight to the maximization of social welfare than the maximization of wealth for shareholders. Therefore, the objectives of SOEs include not only profit but also social aims, such as greater employment. Ghazali (2007) contends that a government owned company is more politically sensitive. It is because the activities of these companies are more in the public eyes. That is because ownership by the government indirectly means that the company is owned by the public at large. Gao (2011) finds that SoEs have higher propensity to address most social issues than non-SoEs. Thus, this type of companies may engage in more socially responsible activities to legitimize their existence. The first hypothesis is:

H1: State owned Enterprises (SoEs) engage in more corporate community contributions than Non-SoEs. 
Past studies on corporate community contributions have noted that type of industry influences the amount of community contributions. Roberts (1992) defines high-profile industries as those with consumer visibility, a high level of political risk or concentrated intense competition. For example, Brammer and Millington (2003) find that industries characterised by significant stakeholder pressure such as tobacco, and alcoholic drinks industries, give more to charitable contributions. Another example is that bank and utilities industries have come under scrutiny from the media and government. In response to negative perceptions of stakeholder, these firms have become significant contributors to community programs (Brammer and Millington 2003). Johnson (1966) in Amato and Amato (2007) argue that firms in the middle, facing the most rivalry, had the greatest incentive to engage in philanthropy. These high rivalry industries would view charitable contributions as a mechanism for differentiating their market position, gaining strategic advantage over other firms in the industry. For instance, Brown et al. (2006) find that pharmaceutical firms give significantly more to health causes than do other firms. They may give to hospitals to build relationships with doctors and hospital administrators who, in turn, may buy their products and provide access for testing new products and drug treatments. Petroleum firms give significantly more to environmental causes than do firms in other industries, perhaps to counterbalance perceptions as being environmentally unfriendly. The second hypothesis is:
H2: Firms in high profile industries will give more in community contributions than those in low profile industries.

\section{RESEARCH METHODOLOGY SampleS election}

This study uses a quantitative empirical research to determinants of community contributions. A sample of 143 companies is selected from a population of 1623 companies listed on the Indonesia Stock Exchange (IDX) from 2008 through 2011 financial year. The selection of the companies is based on the availability of their 2008-2011annual and/or sustainability reports. Data for all variables are collected from these annual and/or sustainability reports.

\section{Measurement of variables}

Table 1 summarizes the measurement of the dependent, independent, and control variables, including industry type; ownership, profitability, and firm size are variables often used in corporate social responsibility studies (Roberts 1992; Brammer and Millington 2003; Amato and Amato 2007; Bartkus et al. 2002; Ghazali, 2007; Li et al. 2013).

\section{Statistical Analysis}

This study employs Ordinary Least Square (OLS) multiple regressions as the main statistical technique to test these hypotheses. The regression models used is:

$$
\begin{gathered}
C C=\beta_{0}+\beta_{1} \text { Ownership }+\beta_{2} \text { Industry type }+ \\
\beta_{3} \text { Profitability }+\beta_{4} \text { Firm size }+\varepsilon
\end{gathered}
$$

Table 1: Variable Measurement

\begin{tabular}{ll}
\hline Variables & Measurement \\
\hline $\begin{array}{l}\text { Dependent: } \\
\text { Community contributions }\end{array}$ & $\begin{array}{l}\text { The amount monetery corporate community contributions made by } \\
\text { firm which is self-reported in annual and/or sustainability reports. }\end{array}$ \\
$\begin{array}{l}\text { Independent: } \\
\text { Industry type } \\
\text { Ownership }\end{array}$ & $1=$ high profile and $0=$ low profile \\
& $1=$ SoEs and $0=$ Non-SoEs \\
$\begin{array}{l}\text { Control: } \\
\text { Profitability }\end{array}$ & ROA: total net profit divided by total assets \\
Firm size & Number of employee \\
\hline
\end{tabular}


Independent sample $t$-tests are also used to test whether there is a significant difference in the amount of community contributions between State-owned enterprises (SoEs) and non-SoEs; and for firms from high profile industries and for those from low profile industries.

\section{RESULTS AND DISCUSSION Descriptive Statistics}

Table 2 shows descriptive statistics for all variables. The overall mean of community contributions are 16.263 billion rupiahs. Table 2 also highlights the key firm characteristics. The mean of number of employee is 8230 employees with a median of 4231 employees. The large gap between mean and median indicates that firm size as proxied by number of employee possesses some extreme values and is skewed $(\min =539$ and $\max =40,044)$. The mean of return on assets (ROA) ratio is 7.94 percent. With regards to ownership type, 39.2 percent of the firms in the sample are classified as SoEs while 60.8 percent are Non-SoEs. Table 2 also reveals that 65.7 percent of these firms high are categorized as profile and 34.3 percent are low profile industries.
The Independent Samples t-tests in Table 3 indicate that the mean community contributions for SoEs are 23.166 billion rupiahs while the mean of Non-SoEs are 11.819 billion rupiahs. From this result, it can be concluded that there are statistically significant differences across SoEs and NonSoEs $(t=2.061 ; p$-value $=0.043)$ with respect to the amount of corporate community contributions. This finding is consistent with Ghazali (2007) and Gao (2011), but inconsistent with $\mathrm{Li}$ et al. (2013). The industry type variable indicates a similar result. The mean of firms from high profile industries far higher (20.306 billion rupiahs) than those low profile ( 8.505 billion rupiahs). These result indicates that there are significant differences between high profile and low profile industries $(\mathrm{t}=$ $3.016 ; \mathrm{p}$-value $=0.003$ ) in regards to the amount of community contributions. Firms from high profile industries are much more likely to be significant community contributors. This finding is consistent with Brammer and Millington (2003), Amato and Amato (2007), Ahmad et al. (2009), and Faisal et al. (2012a, 2012b).

Table 2: Descriptive Statistics

\begin{tabular}{|c|c|c|c|c|c|}
\hline \multicolumn{6}{|l|}{ Continuous variables } \\
\hline Variables & Mean & Median & Std Dev & Minimum & Maximum \\
\hline Com contributions (Bil IDR) & 16.262 & 6.645 & 28.664 & 0.21 & 182.00 \\
\hline Firm size (number of employee) & 8230 & 4231 & 9508 & 539 & 40,044 \\
\hline Profitability (\%) & 7.945 & 3.850 & 8.673 & -0.970 & 41.620 \\
\hline \multicolumn{6}{|l|}{ Categorical variables } \\
\hline Variables & Frequency & & & $\%$ & \\
\hline \multicolumn{6}{|l|}{ Ownership: } \\
\hline SoE & 56 & & & 39.2 & \\
\hline Non-SoE & 87 & & & 60.8 & \\
\hline \multicolumn{6}{|l|}{ Industry: } \\
\hline High Profile & 94 & & & 65.7 & \\
\hline Low Profile & 49 & & & 34.3 & \\
\hline$N=163$ & & & & & \\
\hline
\end{tabular}

Table 3: Independent samples t-tests

\begin{tabular}{|c|c|c|c|}
\hline Community contributions & Mean & t-value & p-value \\
\hline Ownership & & 2.061 & $0.043^{* *}$ \\
\hline SoE $(N=56)$ & 23.1668 & & \\
\hline Non-SoE $(\mathrm{N}=87)$ & 11.8190 & & \\
\hline Industry & & 3.016 & $0.003 * * *$ \\
\hline High profile $(\mathrm{N}=94)$ & 20.3068 & & \\
\hline Low profile $(\mathrm{N}=49)$ & 8.5052 & & \\
\hline
\end{tabular}


Table 4: Pearson correlation

\begin{tabular}{lccccc}
\hline & 1 & 2 & 3 & 4 & 5 \\
\hline 1. Community contributions & 1 & $.194^{* *}$ & $.196^{* *}$ & $.170^{* *}$ & .070 \\
2. Ownership & $.194^{* *}$ & 1 & $-.175^{* *}$ & -.001 & .013 \\
3. Industry & $.196^{* *}$ & $-.175^{* *}$ & 1 & .107 & .041 \\
4. Profitability & $.170^{* *}$ & -.001 & .107 & 1 & .037 \\
5. Firm size & .070 & .013 & .041 & .037 & 1 \\
\hline
\end{tabular}

$* * *, * *, *$ denote significance at the $1 \%, 5 \%, 10 \%$ level of confidence, respectively.

\section{Multivariate Analysis}

Table 5. Multiple regression analysis

\begin{tabular}{lcccl}
\hline Variables & Predicted Sign & Coefficient & t-value & p-value \\
\hline Intercept & + & -15.453 & -0.790 & 0.431 \\
Ownership & + & 13.715 & 2.883 & $0.005^{* * *}$ \\
Industry & + & 12.951 & 2.619 & $0.010^{* * *}$ \\
Profitability & + & 0.485 & 1.825 & $0.070^{*}$ \\
Firm size (log) & 3.821 & 0.727 & 0.468 \\
\hline Adjusted $\mathrm{R}^{2}$ & 0.091 & \\
F-value & 4.565 & \\
Prob. (F) & 0.002 & \\
$\mathrm{~N}=163$ & \\
$* * * * *, *$ denote significance at the $1 \%, 5 \%, 10 \%$ level of confidence, respectively.
\end{tabular}

Table 5 presents the multiple regression results for the 143 sample companies. The results are consistent with the independent sample t-test and correlation analysis (see Table 4 for details), it supports the hypothesis that SoEs tend to involve in more community contributions compared to Non SoEs $(\mathrm{t}=2.882$; $\mathrm{p}$-value $=0.005)$. Similarly, the type of industry is also a significant and statistically positive relationship with community contributions $(\mathrm{t}=2.619 ; \mathrm{p}$-value $=0.010)$.

Overall, the regression results in Table 5 lead to the following conclusions.

- H1 is supported. Based on stakeholder theory perspective, SoEs engage in more community contributions compared to Non-SoEs.

- H2 is supported. Based on legitimacy tenets, high profile industries tend to involve in more than low profile industries.

- Profitability and firm size do not have an impact on the relationship between predictor variables and community contributions in driving companies to engage in more corporate community contributions. The results indicate that profitability is not a predictor of community contributions. This finding largely supports the previous findings (see for example Seifert et al. 2004; Chai 2010). This result suggests that community contributions are more closely associated with public pressure rather than economic pressure. The insignificance of the firm size is also consistent with Seifert et al. (2004). This finding can be explained by reflection of the sample utilized The reason for this statistically insignificant result may be that the sample of this thesis is dominated by large companies. The result suggests that the size of these large companies is insufficiently different from each other to affect their amount of contributions.

\section{CONCLUSIONS}

This study notes that the type of ownership is related to the amount of community contributions. From stakeholder theory viewpoint, the result provides support that firms may reap benefits from community contributions and obtain cooperation and support from stakeholders such as employees, customers, and 
local community. As argued by Saiia et al. (2003) that community contributions can be regarded as a means by which firms can build better relations with their key stakeholders. From the lens of legitimacy theory, SoEs engage in more community contributions as they are more politically sensitive, because ownership by the government indirectly means that the company is owned by the public at large (Ghazali 2007). Thus, the SoEs may engage in more community contributions activities to legitimize their existence and build an image of good corporate citizenship with external constituencies.

Overall, the finding indicates that SoEs pay much attention to community contributions. SOEs may think that supporting community contributions are a useful way to build their responsible images in front of the government, since they are supervised by the government. The theoretical implication of this finding is that; this study highlights the importance of corporate ownership and shows that different types of corporate ownership lead to different emphases by managers in stakeholder and thus affect community contributions decisions. Government ownership, however, brings more attention to the stakeholders of SoEs and hence influences the community contributions behavior of these firms.

This study also concludes that industry type is as a determinant of community contributions. Firms in high profile industries give more in community contributions. From the stakeholder theory, one important reason why high profile firms practice corporate community contribution is to help them build strategic relationships and coalitions with the government, the press, other firms, customers, and the public at large by bolstering their position in their environments. From the legitimacy tenets, high profile companies tend to be significant contributors in community activities as it may help them to gain brand recognition and loyalty, promote itself as a socially responsible firm, or attract and maintain a work force.

The finding of this study has important managerial implications. The differences of industry in the community contributions culture affect the giving behavior of individual firms. By considering industry characteristics, it could help stakeholders to make better informed business decisions. As argued by Adam and Hardwick (1998) that companies which make substantial contributions to charities and other social causes are likely to promote a socially responsible public image which could extend to other aspect of business practices.

Future research is recommended to further my understanding of corporate community contributions. Future research could extent this study by considering non-monetary of community contributions such in-kind, giving. Giving a products or employee release time for volunteer work seems particularly relevant to strategic community contributions. Such an approach could generate more insights into pattern on community contributions. In addition, other more qualitativelyoriented research techniques could be employed to obtain interview and focus group style data from key senior corporate managers concerning their constraints and incentives to make community contributions decisions.

\section{REFERENCES}

Adam, M., and P. Hardwick. 1998. An analysis of corporate donations: United Kingdom evidence. Journal of Management Studies 35 (5): 641-654.

Ahmad, R. A. R., G. Tower, and J. L. W. M Van der Zahn. 2009. Exploratory analysis of corporate philanthropy disclosure practices and influencing factors in Australia. Financial Reporting, Regulation and Governance 8 (1): 127.

Amato, L. H., dan C. H. Amato. 2007. The effect of firm size and industry on corporate giving. Journal of Business Ethics 72 (3): 229-241.

Amato, L. H., and C. H. Amato. 2012. Retail philanthropy: firm size, industry and 
business cycle. Journal of Business Ethics 107 (4): 435-448.

Ashford, B. E., and D. W. Gibbs. 1990. The Double-edge of organizational legitimation. Organization Science 1 (2): 177-194.

Atkinson, L., and J. Galaskiewicz. 1988. Stock ownership and company contributions to charity. Administrative Science Quarterly 33 (1): 82-100.

Bartkus, B. R., S. A. Morris, and B. Seifert. 2002. Governance and corporate philanthropy: restraining Robin Hood? Business and Society 41 (3): 319-344.

Blagov, Y., and A. Petrova-Savchenko. 2012. Corporate philanthropy in Russia: evidence from a national awards competition. Corporate Governance 12 (4): 534-547.

Brammer, S. J., and A. Millington. 2003. The evolution of corporate charitable contributions in the UK between 1989 and 1999: industry structure and stakeholder influences. Business Ethics: A European Review 12 (3): 216-228.

Brammer, S. J., and A. Millington. 2004. Stakeholder pressure, organizational size, and the allocation of departmental responsibility for the management of corporate charitable giving. Business and Society 43 (3): 268-295.

Brammer, S. J., and A. Millington. 2005. Corporate reputation and philanthropy: an empirical analysis. Journal of Business Ethic 61 (2): 29-44.

Brammer, S. J., \& A. Millington. 2006. Firm size, organizational visibility and corporate philantrophy: an empirical analysis. Business Ethics: A European Review 15 (1): 6-18.

Brammer, S. J., S. Pavelin and L. A. Porter. 2009. Corporate charitable giving, multinational companies and countries of concern. Journal of Management Studies 46 (4): 575-596.
Brown, W. O., E. Helland, and J. K. Smith 2006. Corporate philanthropic practices. Journal of Corporate Finance 12 (5): 855-877.

Buchholtz, A. K., A. C. Amason, and M. A. Rutherford. 1999. Beyond resources: the mediating effect of top management discretion and values on corporate philanthropy. Business and Society 38 (2): 167-187.

Campbell, D., G. Moore, and M. Metzger. 2002. Corporate philanthropy in the U.K. 1985-2000: Some empirical findings. Journal of Business Ethics 39 (1): 29-41.

Campbell, D., and R. Slack. 2006. Public visibility as the determinant of the rate of corporate charitable donations. Business Ethics: A European Review 15 (1): 19-28.

Campbell, D., G. Moore, and P. Shrives. 2006. Cross-sectional effects in community disclosure. Accounting, Auditing, and Accountability Journal 19 (1): 96-114.

Campbell, D., and R. Slack. 2008. Corporate philanthropy strategy and strategic philanthropy: some insights from voluntary disclosures in annual reports. Business and Society 47 (2): 187-212.

Chen, J. C., D. M. Patten, and R. W. Roberts. 2008. Corporate charitable contributions: a corporate social performance or legitimacy strategy? Journal of Bussines Ethics82 (1) : 131-144.

Collins, M. 1994. Global corporate philantrophy and relationship marketing. European Management Journal 12 (2): 226-233.

Cowan, A., C. H. Huang, P. Padmanabhan, and C. H. Wang. 2013. The determinants of foreign giving: An exploratory investigation of US manufacturing firms. International Business Review 22 (2): 407-420. 
Dowling, J., and J. Pfeffer. 1975. Organizational legitimacy: social values and organizational behaviour. Pacific Sociological Review 18 (1): 122-136.

Faisal, F., Tower, G., and R. Rusmin. 2012a. Legitimising corporate sustainability reporting throughout the world. Australasian Accounting Business and Finance 6 (2): 19-34.

Faisal, F., Tower, G., and R. Rusmin. 2012b. Communicating key labour issues in a global context. Journal of Human Resource Costing and Accounting 16 (4): 320-340.

Freeman, R. E. 1984. Strategic management: a shareholder approach. Boston: Pitman/Ballinger.

Ghazali, N. A. M. 2007. Ownership structure and corporate social responsibility disclosure: some Malaysian evidence. Corporate Governance 7 (3): 251-266.

Gao, Y. 2011. CSR in an emerging country: a content analysis of CSR reports of listed companies. Baltic Journal of Management 6 (2): 263-291.

Godfrey, P. C., and N. Hatch. 2007. Researching corporate social responsibility: an agenda for the 21 st century. Journal of Business Ethics 70 (1): 87-98.

Gray, R., R. Kouhy, and S. Lavers. 1995. Corporate social and environmental reporting: a review of the literature and a longitudinal study of UK disclosure. Accounting, Auditing and Accountability Journal 8 (2): 47-77.

Gunawan, J., H. Djajadikerta, and M. Smith. 2009. An examination of corporate social disclosures in the annual reports of Indonesian listed companies. Journal of the Asia-Pacific Centre for Environmental Accountability 15 (1): 1336.

Gunawan, J. 2010. Perceptions of important information in corporate social disclo- sures: Evidence form Indonesia. Social Responsibility Journal 6 (1): 62-71.

Hidayati, N.D. 2011. Pattern of corporate social responsibility programs: A case study. Social Responsibility Journal 7 (1): 104-117.

Kabongo, J. D., K. Chang, and Y. Li. 2012. Impact of operational diversity on corporate philanthropy: an empirical study of U.S. companies. Journal of Business Ethics doi: 10.1007/s10551-012-14459.

Li, Q., W. Luo, Y. Wang, and L. Wu. 2013. Firm performance, corporate ownership, and corporate social responsibility disclosure in China. Business Ethics: A European Review 22 (2): 1-15.

Mirfazli, E. 2008. Corporate social responsibility (CSR) information disclosure by annual reports of public companies listed at Indonesia Stock Exchange (IDX). International Journal of Islamic and Middle Eastern Finance and Management 1 (4): 275-284.

Porter, M. E, and M. R. Kramer. 2002. The competitive advantage of corporate philantrophy. Harvard Business Review 80 (12): 56-68.

Reverte, C. 2009. Determinants of corporate social responsibility disclosure ratings by Spanish listed firms. Journal of Business Ethics88 (2) : 351-366.

Roberts, R. W. 1992. Determinants of corporate social responsibility disclosure: an application of stakeholder theory. Accounting, Organizations and Society 17 (6): 595-612.

Saiia, D. H., A. B. Carroll, and A. K Buchholtz. 2003. Philanthropy as strategy: When corporate charity "begins at home." Business and Society 42 (2): 169-201.

Sanchez, C. M. 2000. Motives for corporate philanthropy in El Savador: Altruism 
and political legitimacy. Journal of business ethics 27 (4): 363-375.

Siregar, S. V., and Y. Bachtiar. 2010. Corporate social reporting: Empirical evidence from Indonesia stock exchange. International Journal of Islamic and Middle Eastern Finance and Management 3 (3): 241-252.

Smith, J. K. 2012. Corporate philanthropy. In H. K. Baker., and J. R. Nofsinger (Editors), socially responsible finance and investing: Financial institutions, corporations, investors, and activists. John Wiley \& Sons.
Van der Laan Smith, J., A. Adhikari, and R. H. Tondkar. 2005. Exploring differences in social disclosure internationally: A stakeholder perspective. Journal of Accounting and Public Policy 24 (2): 123-151.

Wang, H., and C. Qian. 2011. Corporate philantrophy and and corporate financial performance: the roles of stakeholder response and political access. Academy of Management Journal 54 (6): 11591181. 